\title{
DAKWAH PADA MASA NABI MUHAMMAD SAW. (Studi Naskah Dakwah Nabi Muhammad Pada Periode Madinah)
}

\author{
Oleh: St. Nasriah \\ Fakultas Dakwah dan Komunikasi \\ UIN Alauddin Makassar
}

\begin{abstract}
:
On the stage of history, propagation of the Prophet is divided into two periodisations namely the period of Mecca and Medina. Both of these periods have their own character and strategy, this can be seen from the extent to which the results achieved by the Prophet in the period of Mecca and Medina. Historians give categorization that Prophet's propagation in Mecca is characterized by aqidah planting mission to the ummah, while in Madinah it is more inclined towards social and legal development. In Medina, the Prophet Muhammad. Continue broadcasting Islam to the inhabitants of the unbelieving Madinah. He invited the Jews and Christians to believe in him. Some of them were converts to Islam, but most of them held their religion firmly.
\end{abstract}

\section{Keywords: \\ Da'wah, Period, Medina}

\section{PENDAHULUAN}

Dakwah pada masa Nabi Muhammad saw. adalah sebuah penomena yang cukup spektakuler. Dalam pengertian bahwa Nabi Muhammad saw. telah mampu menjadi pioner dunia tidak hanya dalam lingkup orang-orang Arab kala itu, akan tetapi bagi seluruh alam semesta, yang dalam catatan sejarah hasilnya diperoleh dalam kurun waktu yang relatif singkat.

Pada pentas sejarah, dakwah Nabi dibagi ke dalam dua periodisasi yakni periode Mekah dan Madinah. Kedua periode ini memiliki karakter dan strategi masing-masing, hal ini dapat dilihat dari sejauh mana hasil yang telah dicapai oleh Nabi pada periode Mekah dan Madinah. Para sejarawan memberikan kategorisasi bahwa dakwah Nabi di Mekah bercirikan dengan misi penanaman aqidah terhadap umat, sementara di Madinah lebih cenderung terhadap pembangunan sosial kemasyarakatan dan hukum.

Dalam perjalanan dakwah yang dilakukan oleh Nabi Muhammad saw. menghadapi masyarakat plural ketika berada di Madinah, masyarakat Madinah pada waktu itu sangat plural, diketahui memiliki keyakinan (agama) yang bermacam-macam, suku, ras, warna kulit dan lain-lain.

Dakwah adalah perjuangan yang memerlukan ketegaran dan ketabahan. Meski Rasulullah saw. menghadapi berbagai tantangan, namun semuanya beliau lalui dengan sabar dan konsisten. Refleksi atas perjuangan Rasulullah saw. khususnya ketika menghadapi berbagai tantangan dari pembesar-pembesar yang ada di Kota Medina. Dalam Alquran, salah 
satu tantangan besar dalam dakwah adalah orang-orang kaya yang berpengaruh tetapi mereka durhaka. Mereka itulah yang disebut Alquran sebagai "mutrafin", yang menyebabkan hancurnya suatu negeri. Perilaku kaum mutrafin dilukiskan dalam Q.S. al-Isra'(17): 16, berikut ini.

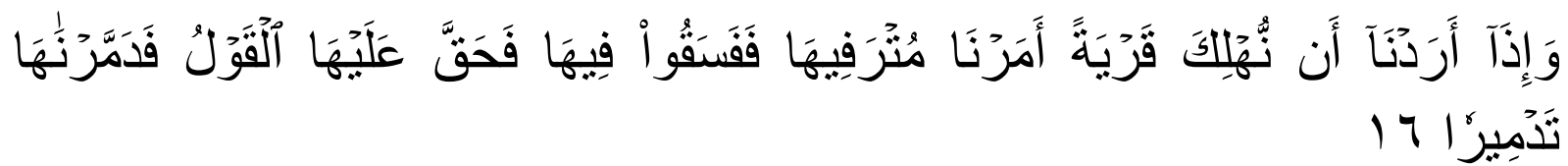

Terjemahnya:

Dan jika Kami hendak membinasakan suatu negeri, maka Kami perintahkan kepada orang-orang yang hidup mewah di negeri itu supaya menaati Allah tetapi mereka melakukan kedurhakaan dalam negeri itu, maka sudah sepantasnya berlaku terhadapnya perkataan (ketentuan Kami), kemudian Kami hancurkan negeri itu sehancur-hancurnya. ${ }^{1}$

Menurut M. Quraish Shihab, ayat tersebut menjelaskan salah satu sunatullah yang berlaku untuk jatuhnya suatu siksa bagi kaum yang durhaka. Secara tidak langsung ayat itu mengatakan: "Dan jika kami hendak membinasakan suatu negeri yang durhaka, sesuai dengan ketetapan dan kebijaksanaan Kami, maka Kami perintahkan orang-orang yang hidup mewah di dalamnya, yakni di negeri itu supaya menaati Allah dan Rasul-Nya, tetapi mereka enggan lalu mereka melakukan kedurhakaan yakni penganiayaan dan pengrusakan di dalamnya yakni di negeri itu, maka sudah sepantasnya berlaku terhadapnya perkataan yakni ketentuan Kami, maka Kami menghancurkan penduduk negeri itu dan atau bersama negeri itu sehancurhancurnya sehingga mereka tidak bangkit lagi sebagai satu orde atau sistem kemasyarakatan. ${ }^{2}$

Menyimak argumentasi yang dikemukakan di atas maka dapat dipahami bahwa Nabi saw. dalam melaksanakan dakwah pada periode Madinah menghadapi tantangan yang relatif berat. Dalam pengertian bahwa Nabi saw. menghadapi orang-orang (kelompok) yang berpengaruh baik dari segi status sosial maupun dari segi kemampuan pinansial. Menghadapi kelompok tersebut tidaklah mudah, karena memiliki pengaruh yang besar di tengah-tengah masyarakat Madinah kala itu.

\section{PEMBAHASAN}

Deskripsi Naskah

\section{Biografi Singkat Nabi Muhammad SAW. Sebelum dan Sesudah Masa Kerasulan}

Nabi Muhammad saw. adalah keturunan Bani Hasyim, suatu kabilah yang kurang berkuasa dalam suku Quraisy. Nabi Muhammad lahir dari keluarga terhormat yang relatif miskin. Ayahnya bernama Abdullah anak Abdul Muthalib, seorang kepala suku Quraisy yang besar pengaruhnya. Ibunya adalah St. Aminah binti Wahab dari Bani Zuhrah. Muhammd lahir dalam keadaan yatim karena ayahnya (Abdullah bin Abdul Muthalib), meninggal dunia 3 bulan setelah dia menikahi Aminah. Muhammad kecil kemudian diserahkan kepada ibu pengasuh, Halimah Sa'diyyah. Dalam asuhannyalah Muhammad kecil dibesarkan sampai usia 4 tahun. Setelah itu, kurang lebih 2 tahun dia berada dalam asuhan ibu kandungnya. Ketika 
berusia 6 tahun, dia menjadi yatim piatu. Seakan-akan Allah ingin melaksanakan sendiri pendidikan terhadap Muhammad, orang yang dipersiapkan untuk membawa risalah-Nya yang terakhir. $^{3}$

Setelah Aminah meninggal, Abdul Muthalib mengambil alih tanggung jawab merawat Muhammad. Namun, 2 tahun kemudian Abdul Muthalib meninnggal dunia karena sudah berumur. Tanggung jawab selanjutnya beralih kepada pamannya, Abu Thalib. Seperti juga Abdul Muthalib, dia sangat disegani dan dihormati orang Quraisy dan penduduk Mekah secara keseluruhan, tetapi dia miskin." 4

Dalam usia muda, Muhammad hidup sebagai penggembala kambing keluarganya dan penduduk Mekah. Melalui kegiatan pengembalaan ini dia menemukan tempat untuk berpikir dan merenung. Dalam suasana demikian, dia ingin melihat sesuatu dibalik semuanya. Pemikiran dan perenungan ini membuatnya jauh dari segala pemikiran nafsu duniawi, sehingga ia terhindar dari berbagai macam noda yang dapat merusak namanya, karena itu sejak muda beliau sudah dijuluki "al-ami>n", orang yang terpercaya. Nabi Muhammad ikut untuk pertama kali dalam kafilah dagang ke negeri Syria (syam) dalam usia baru 12 tahun. Kafilah itu dipimpin oleh Abu Thalib. Dalam perjalanan ini, di Bushra, sebelah selatan Syria, ia bertemu dengan pendeta Kristen yang bernama Buhairah. ${ }^{5}$

Dengan demikian Muhammad muda telah diajarkan untuk bekerja keras dan hidup mandiri oleh pamannya, usaha dan kerja kerasnya tidak sia-sia yang pada akhirnya dapat mengantarkannya menjadi manusia teladan dan pilihan dari Allah awt. Selanjutnya untuk mendapatkan gambaran singkat bagaimana silsilah atau asal-usul Nabi Muhammad saw. maka dapat diperhatikan pada skema dibawah ini, yaitu sebagai berikut: 


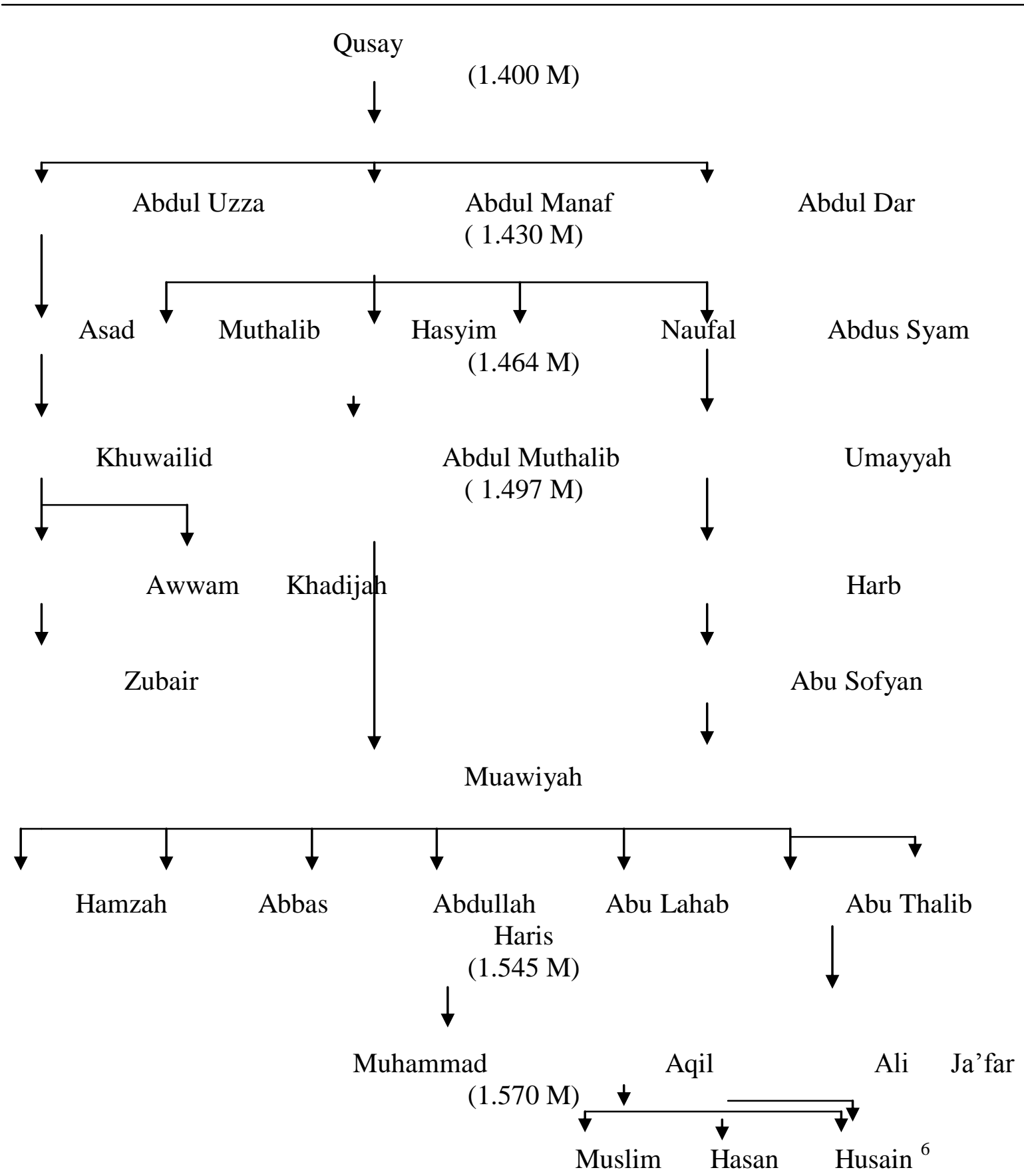

Sudah menjadi kebiasaan orang Arab kala itu, apabila ingin berfikir jernih dan serius, maka ia harus meninggalkan keramaian (bertahannus), begitu pula yang dilakukan oleh Muhammad saw. Beliau menyendiri di gua Hira, ketika usia beliau telah mencapai 40 thn, jiwanya sudah penuh iman, Allah telah mendidiknya melalui berbagai mimpi, sehingga sekitar tahun $610 \mathrm{M}$, tatkala ia sedang tidur dalam gua, Jibril datang membawa wahyu yang pertama yaitu surah al'-Alaq. ${ }^{7}$ (QS. al-'Alaq [96]: 1-5) sebagai berikut : 


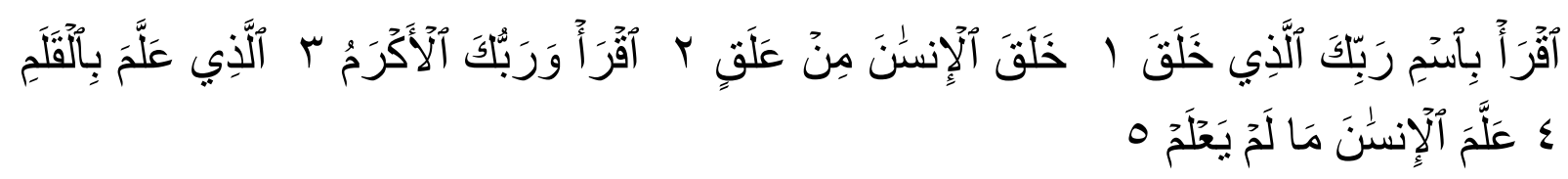

Terjemahnya:

Bacalah dengan menyebut nama Tuhanmu yang menciptakan, Dia telah menciptakan manusia dari segumpal darah. Bacalah, dan Tuhanmulah yang maha pemurah, yang mengajar manusia dengan perantaran kalam. Dia mengajar kepada manusia apa yang tidak diketahuinya. ${ }^{8}$

Turunnya ayat di atas, sebagai titik awal bahwa pengangkatan beliau sebagai seorang rasul telah mulai, sehingga konsekuensi yang harus dijalankan untuk mendakwahkan Islam kepada umat manusia khususnya masyarakat Arab kala itu sudah harus siap ia laksanakan. Dengan turunnya wahyu pertama ini, beliau belum diperintahkan untuk berdakwah kepada manusia.

Saking kagetnya Nabi Muhammad saw. badannya menggigil ketika pulang ke istrinya tercinta, Hadijah yang dengan bijaksana ikut merasakan apa yang terjadi pada suaminya. Lalu Hadijah pergi menemui Waraqah ibn Naufal, anak pamannya yang ahli kitab (Nasrani) yang telah menterjemahkan sebagian injil ke dalam bahasa Arab, menanyakan gerangan apa yang tersembunyi dibalik peristiwa yang belum pernah dialami oleh Nabi Muhammad saw. Waraqah mengatakan bahwa Nabi Muhammad saw. akan menjadi orang pilihan dengan katanya:

"Maha Qudus ia, Maha Qudus, demi dia yang memegang hidup Waraqah. Hadijah, percayalah, ia telah menerima Namus besar seperti yang diterima Musa. Dan sungguh ia adalah Nabi ummat ini, katakan kepadanya supaya tetap tabah".

Dalam suatu kesempatan Waraqah berkata sendiri kepada Muhammad bahwa ia telah menerima namus besar sebagaimana telah diterima Musa, dan ia akan didustakan orang, disiksa, diusir dan diperangi, bila saja pada saat itu Waraqah masih hidup ia akan membela yang benar dipihak Allah. ${ }^{10}$

Setelah turunnya ayat pertama, Jibril tidak datang untuk beberapa lama, sementara Nabi Muhammad menantikannya dan selalu datang ke gua hira. Dalam keadaan menanti itulah turun wahyu yng membawa perintah kepadanya, (QS. al-Mudatssir [74]:1-7) wahyu itu berbunyi sebagai berikut :

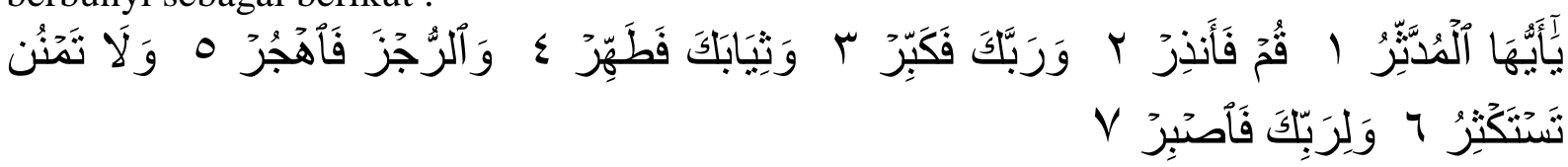

Terjemahnya:

Hai orang yang berkemul (berselimut). Bangunlah dan berilah peringatan.Dan Tuhanmu agungkanlah. Dan pakaianmu bersihkanlah. Dan perbuatan dosa tinggalkanlah. Dan janganlah kamu memberi dengan maksud memperoleh balasan yang lebih banyak. Dan untuk memenuhi perintah Tuhanmu, bersabarlah. ${ }^{11}$ 


\section{Metode Dakwah Nabi Muhammad di Madinah}

Di Madinah, Nabi Muhammad saw. Terus menyiarkan Islam kepada penduduk Madinah yang belum beriman. Beliau mengajak orang-orang Yahudi dan Nasrani untuk beriman kepadanya. Beberapa di antara mereka ada yang masuk Islam, namun sebagian besar dari mereka tetap memegang teguh agamanya.

Bukan hanya sampai di situ, beliau juga menyampaikan dakwah kepada kabilahkabilah di sekitar Madinah. Dalam waktu yang relatif singkat, jumlah orang yang masuk Isla $>$ m meningkat pesat. Sehingga lama-kelamaan kaum Muslimin Madinah menjadi kelompok mayoritas dan memegang kekuasaan politik. ${ }^{12}$

Pada periode Madinah ini, Nabi Muhammad saw. Mulai mengajarkan ritual-ritual keagamaan seperti shalat dan puasa. Di samping itu, beberapa aturan-aturan sosial kemasyarakatan juga mulai diperkenalkan ${ }^{13}$. Pada perioe Madinah inilah ajaran Islam semakin disempurnakan. Meskipun demikian, sempurnanya ajaran Islam yang diturunkan oleh Allah swt. Baru ditetapkan setelah beliau sedang mengerjakan wukuf di Arafah dengan turunnya wahyu terakhir sebagaimana tercantung dalam Q.S. Al-Maidah (5): 3 sebagai berikut:

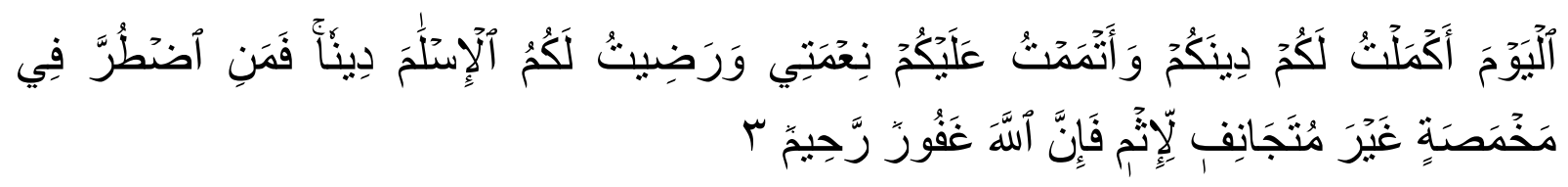

Terjemahnya :

Pada hari Ini Telah Kusempurnakan untuk kamu agamamu, dan Telah Ku-cukupkan kepadamu nikmat-Ku, dan Telah Ku-ridhai Islam itu jadi agama bagimu. ${ }^{14}$

Ayat tersebut di atas menyatakan bahwa pada hari ini Allah menyempurnakan ajaran Islam yang dibawa oleh Nabi Muhammad saw. Dengan demikian secara tidak langsung Allah menyatakan bahwa tugas kerasulan beliau sudah hampir selesai. Di Madinahlah beliau membuat suatu perjanjian bersama masyarakat Madinah yang terdiri dari satu muqaddimah dan sepuluh Bab. yang disebut dengan piagam Madinah . Adapun teksnya sebagai berikut

Salinan Teks Piagam Tertulis Nabi Muhammad saw. 


\section{Teks Aslinya}

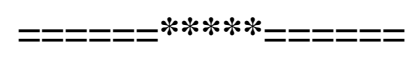

\section{MUKADDIMAH}

Dengan Nama Tuhan YANG MAHA PENGASIH dan

MAHA PENYAYANG

Inilah piagam tertulis dan Nabi Muhammad saw. Di kalangan orang-orang yang beriman dan memeluk Islam (yang berasal) dari Quraisy dan Yatsrib, dan orang-orang yang mengikuti mereka, mempersatukan dari dari berjuang bersama mereka.

\section{Pembentukan Umat.}

\section{Pasal 1}

Sesungguhnya mereka mereka adalah bangsa-negara (umat), bebas dari (pengaruh dan kekuasaan) manusia lainnya.

II. Hak Asasi Manusia.

Pasal 2.

Kaum Muhajirien dan Quraeisy tetap mempunyai hak dari (formerCondition) dara (diyat) di antara mereka (karena suatu pembunuhan),dengan cara yang baik antara orang-orang beriman.

Pasal 3.

1. Banu'Awf (dari Yatsrib) tetap mempunyai hak asli mereka, tanggung menanggung uang tebusan darah.

2. Dan tiap-tiap keluarga dari mereka membayar bersama akan uang baik dan adil di tebusan dengan antara orang-orang beriman.

Pasal 4.

3. Banu Sa'idah dari (Yatsrib) tetap ats hak asli mereka, tanggung menanggung atas uang tebusan mereka.

4. Dan setiap keluaarga dari merek membayar bersama akan uang Tebusan dengan baik dan adil di antara orang-orang beriman.

Pasal 5.

1. Banu'I Harts (dari suku Yastrib) tetap berpegang atas hak-hak asli mereka. Saling tanggung menanggung untuk membayar uang tebusan dara (diyat) di antara mereka.

2. Setiap keluarga (thaifah) dapat membayar tebusan dengan secara baik dan adil di kalamgan orang-orang beriman.

Pasal 6.

1. Banu Jusyam (dari suku Yastrib) tetap berpegag atas hak-hak asli mereka tanggung menanggung untuk membayar uang tebusan dara (diat) di antara mereka.

2. Setiap keluarga (Thaifah) dapat membayar uang tebusan dengan secara baik dan adil di kalangan orang-orang beriman.

Pasal 7. 
1. Banu Najjar (dari suku Yastrib) tetap berpegang atas hak-hak asli mereka, tanggung menanggung unatuk membayar tebusan dara (diyat) di antara mereka.

2. Setiap keluarga (thaifah) dapat membayar uang tebusan dengan secara baik dan adil di kalangan orang-orang beriman.

Pasal 8.

1. Banu Amrin bin Auf (dari suku Yastrib) tetap berpegang atas hak-hak asli meraka, tanggung menanggung untuk membayar uang tebusan darah (diat)di antara mereka.

2. Setiap keluarga (Thaifah) dapat membuat uang tebusan dengan baik dan adil di kalangan orang-orang yang beriman

Pasal 9.

1. Banu en Nabiet (dari suku Yastrib) tetap berpegang atas hak-hak asli mereka, tanggung menanggung utnuk membayar uang tebusan dara (diyat) di antara mereka.

2. Setiap Keluarga (thaifah) dapat membayar uang tebusan dengan baik dan adil di kalanganorang-orang yang beiman.

Pasal 10.

1. Banu'l Aws (dari suku Yastrib) tetap berpegang atas hak-hak asli mereka, tanggung menanggung utnuk membayar uang tebusan dara (diyat) diantara mereka

2. Setiap Keluarga (thaifah) dapat membayar uang tebusan dengan baik dan adil di kalangan orang-orang yang beiman.

III. Persatuan Seagama.

Pasal 11.

Sesungguhnya orang-orang yang beriman tidak akan tidak akan melalaikan tanggung jawabnya untuk member sumbangan bagi orang-orang yang berhutang karena membayar uang tebusan darah dengan secara baik dan adil di kalangan orang-orang yang beriman.

Pasal 12.

Tidak seorangpun dari orang-orang yang beriman dibolehkan membuat persekutuan denga teman sekutu dari orang-orang yang beriman lainnya, tanpa persetujuan terlebih dahulu dari

padanya.

Pasal 13.

1. Segenap orang-orang yang iman yang bertaqwa harus menentang setiap oran $g$ yang berbuat kesalahan, melanggar ketertiban, penipuan, permusuhan dan pengacauan di

kalangan masyarakat orang-orang yang beriman.

2. Kebulatan persatyuan mereka terhadap orang-orang yang bersalah merupakan tangan yang satu, walaupun terhadap anak-anak mereka sendiri.

Pasal 14.

1.Tidak diperkenankan seseorang yang beriman membunuh seorang yang beriman yang lainnya karena lantaran seorang yang tidak beriman.

2.Tidak pula diperkenankan seoang yang beriman membantu seorang yang kafir untuk melawan seorang yang beriman lainnya.

Pasal 15.

1. Jaminan Tuhan adalah satu dan merata, melindungu nasib orang-orang yang lemah. 
2. Segenap orang-orang yag beriman harus jamin menjamin dan setia kawan sesama mereka dari pada (gangguan) manusia lainnya.

IV. Persatuan Segenap Warga-Negara.

Pasal 16.

Bahwa sesungguhnya kaum-bangsa Yahudi yang setia kepada (negara) kita, berhak mendapat bantuan dan pwrlindungan, tidak boleh dikurangi haknya dan tidak boleh diasigkan dari pergaulan umum.

Pasal 17.

1. Perdamaian dari orang-orang yang beriman adalah satu.

2. Tidak diperkenankan golongan orang-orang yang beriman membuat perjanjian tanpa ikut sertanya segolongan lainnya di dalam suatu peperangan di jalan Tuhan, kecuali atas dasar

persamaan dan adil di antara mereka.

Pasal 8.

Setiap penyerangan yang dilakukan terhadap kita, merupakan tantangan terhadap semuanya, yang harus memperkuat persatuan antara segenap golongan.

Pasal 19.

1. Segenap orang-orang yang beriman harus memberikan pembelaan atas tiap-tiap darah yang tertumpah di jalan Tuhan.

2. Setiap orang beriman yang bertaqwa harus berteguh hati dari atas jalan yang baik dan kuat. Pasal 20.

1. Perlindungan yang diberikan oleh seorang yang tidak beriman (musyrik) terhadap harta dan jiwa seorang musuh Quraeisy, tidaklah diakui.

2. Campur gangan apapun tidaklah diizinkan, atas kerugiannya seorang yang beriman. Pasal 21.

1. Barang siapa yang membunuh akan seorang yang beriman dengfan cukup buktiatas perbuatannya, harus dihukum bunuh atasnya, kecuali kalau wali (keluarga yang berhak) dari si-terbunuh bersedia menerima ganti kerugian.

2. Segenap warga yang berima harus bulat bersatu mengutuk perbuatan itu, dan tidak diiizinkan selain dari pada menghukum kejahatan itu.

Pasal 22.

1. Tidak dibenarkan bagi setiap orang yang mengakui piagam ini dan percaya kepada

Tuhan dan hari yang akhir, akan membantu orang-orang yang salah, dan memb eri tempat kediaman baginya.

2. Siapa yang memberikan bantuan atau memberi tempat tinggal bagi penghianat-penghianat negara atau orang-orang yang salah , akan mendapat kutukan dan kemurkaan Tuhan di hari kiamat nanti, dan tidak diterima segala pengakua dan penyaksiannya.

Pasal 23.

Apa bila timbul perbedaan pendapat di antara kamu di dalam suatu soal, maka kembalikanlah penyelesaiannya kepada (huku) Tuhan dan keputusan Muhammad.

V. Golongan Minoritas.

Pasal 24.

Warga Negara (dari golongan) Yahudi memikul beaya bersama-sama dengan kaum beriman, selama negara dalam peperangan. 
Pasal 25.

1. Kaum Yahudi dari suku Banu 'Awf adalah satu bangsa negara (ummah) dengan warga yang beriman.

2. Kaum Yahudi bebas memeluk agama mereka, sebagai kaum muslimin bebas memeluk agama mereka.

3. Kebebasan ini berlaku juga terhadap pengikut-pengikut/sekutu-sekutu mereka, dan diri mereka sendiri.

4. Kecuali kalau ada yang mengacau dan berbuat kejahatan, yang menimpah diri orang yang bersangkutan dan keluarganya.

Pasal 26.

Kaum Yahudi dari Banu Najjar diperlakukan sama seperti kaum Yahudi dari Banu 'Awf di atas.

Pasal 27.

Kaum Yahudi dari Bani'l Harts, diperlakukan sama seperti kaum Yahudi dari Banu 'Awf di atas.

Pasal 28.

Kaum Yaudi dari Bani Sa’idah, diperlakukan sama seperti kaum Yahudi dari Bani 'Awf.

Pasal 29.

Kaum Yahudi dari Bani Jusyam, diperlakukan sama seperti kaum Yahudi dari Bani 'Awf. Pasal 30. Kaum

Yahudi dari Bani Aws, diperlukan sama seperti kaum Yahudi dari Bani ‘Awf.

Pasal 31.

1.Kaum Yahudi dari Bani Tsa'lahah, diperlakukan sama seperti kaum Yahudi dari Bani 'Awf. 2.Kecuali orang yang mengacau atau berbuat kejahatan, maka ganjaran dari pengacauan atau kejahatan itu menimpah dirinya dan keluarganyha.

Pasal 32.

Suku Jafna adalah bertali darah dengan kaum Yahudi dari Bani Tsa'labah, diperlakukan sama seperti Bani Tsa'laban.

Pasal 33.

1. Banu Syutheibah diperlakukan sama sepert Sikap yang baik harus dapat membendung segala penyelewengan.

Pasal 34.

Pengikut-pengikut/sekutu dari Tsa'labah, diperlakukan sama seperti Banu Tsa'labah. Pasal 35.

Segala pegawai-pegawai dan pembela-pembela kaum Yahudi, diperlakukan sama seperti kaum Yahudi.

VI. Tugas Warga Negara

Pasal 36

1. Tidak seorang pun warga Negara yang dibolehkan bertindak keluar, tanpa izionnya Muhammad, mudah-mudahan Tuhan mencurahkan sel;awat dan salam atasnya. 
2. Seorang warga Negara dapat membalaskan kejahatan luka yang dilakukan orang kepadanya.

3. Siapa yang berbuat kejahatan, maka ganjaran kejahatan itu menimpah dirinya dan keluarganya, kecuali untuk membela diri.

4. Tuhan melindungi atas orang-orang yang setia kepada piagam ini.

Pasal 37.

1. Kaum Yahudi memiliki beaya Negara, sebagai halnya kaum muslimin memikul b eaya Negara.

2. Di antara segenap warga Negara (Yahudi dan Muslimin) terjalin pembelaan untuk menentang setiap musuh Negara yang memerangi setiap peserta dari piagam ini.

3. Diantara mereka harus terdapat saling nasehat menasehati dan berbuat kebajikan, dan menjauhi segala dosa.

4. Seorang warga Negara tidaklah dian ggap bersalah, karena kesalahan yang dibuat sahabat/sekutunya.

5. Pertolongan, pembelaan dan bantuan harus diberikan kepada orang/golongan yang teraniaya. Pasal 38.

Warga Negara kaum Yaudi memikul beaya bersma-sama warga Negara yang beriman, selama peperangan masih terjadi.

VII. Melindungi Negara.

Pasal 39.

Sesungguhnya kota Yastrib, Ibu Kota Negara, tidak b oleh dilanggar kehormatannya oleh setiap peserta piagam ini.

Pasal 40.

Segala tetangga yang berdampingan rumah harus diperlakukan sebagai diri sendiri , tidak boleh diganggu kketenteramannya, dan tidak diperlakukan salah.

Pasal 41.

Tidak seorang pun tetangga wanita oleh diganggu ketenteraman atau kehormatannya, melainkan setiap kunjungan harus dengan izin suaminya.

VIII. Pimpinan Negara.

Pasal 42.

1. Tidak boleh terjadi suatu peristiwa di antara peserta piagam ini, atau terjadi pertengkaran, melainkan segera dilaporkan dan diserahkan penyelesainannya menurut (hukum) Tuhan dan (kebijaksanaan) utusannya Muhammad - mudah-mudahan Tuhan mencurahkan salawat dan salam atasnya.

2. Tuhan berpegang teguh kepada piagam ini dan orang-orang yang setia kepadanya negara/

Pasal 43.

Sesungguhnya (musuh) Qureisy tidak b oleh dilindungi, begitu juga segala orang yang membantu mereka.

Pasal 44.

Di alangan warga Negara sudah terikat janji perthanan bersama untuk menentang setiap aggressor yang menyergap kota Yastrib. 


\section{Politik Peramaian. \\ Pasal 45.}

1. Apa bila mereka diajak kepada perdamaian (dan) membuat perjanjian damai (treaty), mereka tetap sedia untuk berdamai dan membuat perjanjian damai.

2. Setiap kali ajakan perdamaian seperti demikian, sesungguhnya kum yang beriman harus melakukannya, kecuali terhadap orang (Negara)yang menunjukkan permusuhan terhadap agama (Islam).

3. Kewajiban atas setia warga Negara mengambil bahagian dari pihak mereka untuk perdamaian itu.

Pasal 46.

1. Dan sesungguhnya kaum Yahudi dari Aws dan segala sekutu dan simpatisan mereka, mempunyai kewajiban yang sama dengan segala peserta piagam untuk kebaikan (perdamaian) itu.

2. Sesungguhnya keb aikan (perdamaian) dapat menghilangkan segala kesalahan.

\section{Penutup.}

Pasal 47.

1. Setiap orang (warga Negara) yang berusaha, segala usahanya adalah atas dirinya.

2. Sesungguhnya Tuhan menyertai akan segala peserfta dari piagam ini, yang menjalankannya dengan jujur dan sebaik-baiknya.

3. Sesungguhnya tidaklah boleh piagam ini dipergunakan untuk melindungi orang-orang yang zalim dan bersalah.

4. Sesungguhnya (mulai saat ini), oranmgb-oramg yang bepergian (keluar) adalah am,an.

5. Dan orang yang menetap adalah aman pula, kecuali orang-orang yang zalin dan berbuat salah.

6. Sesungguhnya Tuhanmelindungi orang (warga negar) yang baik dan bersikap taqwa (waspada).

7. Dan (akhirnya) Muhammad adalah pesuruh Tuhan, semoga Tuhan mencurahkan selawat dan kesejahteraan atasnya. ${ }^{15}$

\section{Analisis Naskah}

Menyimak naskah yang terkait dengan surat perjanjian Nabi dengan orang-orang Yahudi di atas, dalam pandangan penulis maka setidaknya ada beberapa hal yang dapat ditarik benang merah jika ditinjau dalam perspektif dakwah yaitu: pertama, Nabi saw. mengedepankan persamaan di antara semua penduduk Madinah, sehingga terwujud tatanan hidup bermasyarakat yang damai. Kedua, sebelum Nabi saw. melancarkan dakwahnya, beliau terlebih dahulu memperkenalkan dirinya kepada orang-oraang kafir sebagai utusan (Rasul) Allah. Ketiga, Setiap orang yang terikat perjanjian tersebut berkewajiban untuk konsisten dengan perjanjian itu dan tidak seorangpun dibenarkan untuk saling mengganggu antara satu dengan yang lain. Keempat, sebelum piagam perjanjian dibuat, Nabi saw. terlebih dahulu mengadakan musyawarah dengan berbagai kelompok masyarakat, sehingga tidak terkesan bahwa piagam tersebut dibuat atas keinginan sepihak. ${ }^{16}$ Kelima, bahwa piagam ini dibuat 
menggambarkan betapa pluralnya masyarakat Madinah yang dihadapi oleh beliau kala itu, sehingga tergambar betapa sikap toleran yang luar biasa yang telah dicontohkan oleh Rasulullah saw. Dengan demikian tidak dapat dipungkiri lagi bahwa keberhasilan dakwah beliau tergambar dari kebijaksanaannya dalam mentransformasikan Isla>m kepada oran-orang pada umumnya.

Terkait dengan biografi beliau di mana kelahiran Nabi Muhammad saw. dalam sejarah peradaban manusia telah mampu mewarnai budaya serta membangun mental keagamaan manusia, walaupun pada awalnya hanya berawal dari sebuah gerakan tradisional (sederhana), akan tetapi mampu menuai hasil yang cukup mencengangkan.

Menurut Abd. Moqsith Ghazali Nabi Muhammad saw. adalah pusat keteladanan. Segala ucapan dan tindakannya menjadi rujukan umat Isla $>m$, dulu dan sekarang. Hadisnya menjadi sumber hukum (mashdar al-hukm) kedua setelah Alquran. Begitu tinggi kedudukan Nabi Muhammad saw. Di hadapan umat Isla>m, maka momen-momen penting dalam kehidupannya selalu dikenang, dirayakan, dan diperingati. Mulai dari kelahirannya, pengangkatannya sebagai nabi, pencapaian spiritualnya yang tak termaknai berupa isra'mi`raj hingga perjalanannya dari Mekah ke Madinah. ${ }^{17}$

Berbeda dengan kematian yang merupakan pertanda kesementaraan manusia dan juga keterbatasan seorang nabi, maka kelahiran Nabi Muhammad saw. dianggap sebagai pertanda kehidupan baru, perubahan sosial. Itu sebabnya, jika waktu kelahirannya dirayakan, sementara saat kematiannya tidak. Sebagian umat Isla $>m$ percaya bahwa Nabi Muhammad lahir pada Senin pagi menjelang subuh, 12 Rabiul Awal Tahun Gajah ( 'am al-fil). Disebut begitu karena bertepatan dengan tahun penyerangan "Pasukan Gajah" pimpinan Abrahah (Gubernur Abisinia) ke Kabah.

Namun, dengan merujuk pada buku-buku sejarah, kita akan mengerti bahwa tak ada kepastian tentang jam, hari, tanggal dan bulan kelahiran Muhammad saw. Menurut Ibnu Katsir menjelaskan ${ }^{18}$ keanekaragaman pandangan para ulama tentang kelahiran Nabi. Husain Haekal juga menjelaskan pluralitas pendapat tersebut, menurutnya Nabi Muhammad saw. lahir sekitar 570 M. ${ }^{19}$ Ahmad Syalabi mencatat sebagaimana dikutip oleh Ali Mufrodi Nabi Muhammad lahir pada 12 Rabiul Awal (20 April $571 \mathrm{M}){ }^{20}$

Mengacu dari paparan sejarah yang bersumber dari berbagai literatur di atas, maka setidaknya ada beberapa hal yang penting yang dapat dianalisa khususnya dalam perspektif dakwah.

Pertama, Nabi Muhammad saw. adalah sosok manusia yang yatim serta sederhana, sejak kecil telah mulai merasakan bagaimana pentingnya bekerja keras untuk mencapai sebuah cita-cita yang mulia.

Kedua, Nabi Muhammad saw. adalah sosok manusia yang berkarakter sejak kecil, hal ini lahir dari sebuah proses pengalaman berdagang dan menggembala kambing, walaupun dalam usianya yang relatif belia kala itu, akan tetapi ia mampu menunjukkan kepada 
masyrakat di Arab saat itu bahwa ia adalah seorang anak yang tidak sama dengan yang lain. Seorang anak yang tidak hanya menghabiskan waktunya dengan dunia bermain.

Ketiga, Dalam periodesasi dakwahnya di Mekah, ternyata Nabi saw. mengalami berbagai hambatan dan tantangan dakwah sehingga ia lakukan secara sembunyi-sembunyi, sampai sebelum ada perintah dari Allah SWT. untuk berdakwah secara terang-terangan dilakukan setelah beliau berada di Madinah. Hal tersebut terbukti dengan memperkenalkan diri beliu sebagai seorang rasul kepada seluruh komponenn masyarakat yang ada di Madinah.

Keempat, Konsentrasi dakwah yang dilakukan oleh Nabi pada periodesasi Madinah, berangkat dari proses hijrahnya, beliau lebih menfokuskan pada penanaman keislaman yang sifatnya sosial kemasyarakatan.

\section{SIMPULAN}

Seusai menyimak beberapa untaian sejarah dakwah Nabi saw. khususnya pada periodesasi Mekah, maka dapat disimpulkan sebagai berikut: Kelahiran Nabi Muhammad saw. berada pada tahun Gajah yang disinyalir dengan adanya sekelompok pasukan bergajah yang dipimpin oleh Abraham untuk menghancurkan ka'bah. Beliau sejak kecil berproses menjadi anak yang mandiri yang ditandai dengan keikut sertaan beliau pada pamannya (Abu Thalib) untuk dan membawa barang dagangan menuju Syam. Nabi saw.di Madinah memperioritaskan dakwahnya pada penanaman nilai-nilai keislaman yang sifatnya social kemasyarakatan. Sikap dan priklaku nabi (wujud dakwah bi al-hal) yang selalu konsisten dalam segala hal membuat masyarakat sekitar tertarik mengakui dan mempercayai sebagai seorang yang patut dipercaya menjadi pemimpin. Sehingga tidak heran jika dalam jangka waktu yang relatif singkat dakwah Nabi berhasil dengan prestasi yang mencengankan. Kelihaian Nabi saw. dalam membuat piagam konstitusi dan dalam mewujudkannya saat memimpin pemerintahan kota Madinah tidak ada satu poin dari piagam itu yang dilalaikan, menjadikan seluruh komponen masyarakat merasakan perlakuan keadilan yang luar basa.

\footnotetext{
Endnote

${ }^{1}$ Departemen Agama RI, Al-Qur'an dan Terjemahnya (Semarang: Toha Putra, 1989) ,h.426.

${ }^{2}$ M. Qurais Shihab, Tafsir Al-Misbah ( Vol. 7; Jakarta: Mizan, 2005), h.432.

${ }^{3}$ Badri Yatim, Sejarah Peradaban Islam (Jakarta: PT. Raja Grafindo, 2008). h. 16.

${ }^{4}$ Pada hari ketujuh kelahiran Nabi saw. Abdul Muthalib minta disembelihkan unta, hal ini kemudian dilakukan dengan mengundang makan masyarakat Quraisy... (Muh. Husain Haekal, Hayāt Muhammad, terj. Ali Audah, Sejarah Hidup Muhammad ( Cet. XXXIV; Jakarta: Litera Antar Nusantara, 2007), h. 51.

${ }^{5}$ Muhammad Husain Haekal, ibid., h. 63
} 
${ }^{6}$ Ali Mufrodhi, Islam Di Kawasan Kebudayaan Arab (Cet. I; Jakarta: Logos Wacana ilmu), h. 13

${ }^{7}$ Ibid., h. 80

${ }^{8}$ Departemen Agama RI, op.cit.h. 1079

${ }^{9}$ Ali Mufrodi, op.cit., h. 16

${ }^{10}$ Ibid.

${ }^{11}$ Departemen Agama RI, op. Cit., h. 992

${ }^{12}$ Lihat uhammad Syafii Antonio, Teladan Sukses dalam Hidup dan Bisnis (Jakarta:Pfopehetic Leadership \& Managemen Center, 2007), 138.

${ }^{13}$ Lihat Ibid.

${ }^{14}$ Departemen Agama RI. op. cit., h. 57.

${ }^{15}$ Selengkapnya BacaH. Zainal Abidin Ahmad, Piagam Nabi Muhammad saw. Konstitusi Negara Tertulis Yang Pertama Di Dunia (Jakarfta: Bulan Bintang, 1973), h.21-30. Liaht pula J. Suyuthi Pulungan, Fikhi Siyasah Ajaran, Sejarah dan Pemikiran (Jakarta: LSIK, PT Rajagrafindo Persada, 1995), h. 77-81.

${ }^{16}$ BacaAkram Dhiyauddin Umari, Masyarakat Madani Tinjauan Historis Zaman Nabi, (Jakarta: Gema Insani, 1999), h. 108-109.

${ }^{17} \mathrm{http} / / /$ islamlib.com/id/artikel/kapan-muhammad-saw-lahir/, kamis, 28-10-2010, pukul 13.50 wita

${ }^{18}$ Ibn Katsir, al-Bidayah wa al-Nihayah, (Juz. II; t.p, t.t), h. 260-26

${ }^{19}$ Muh. Husain Haekal, Hayāt Muhammad, diterjemahkan oleh Ali Audah, Sejarah Hidup Muhammad ( Cet. XXXIV; Jakarta: Litera Antar Nusantara, 2007), h. 51.

${ }^{20}$ Ali Mufrodi, op.cit., h. 11

\section{DAFTAR PUSTAKA}

Abdullah,Taufik. Sejarah Lokal di Indonesia, Yokyakarta: Gajamada Universiy Press, 1996

Abul A'la al-Maududi, The Islamic Low and Constitution, Lahore: Islam Publication Ltd, 1976

Abu al Fath al Bayanuni, Muhammad. al-Madkhal ila Ilm al-Da'wah Beirut: Muassasah alRisalah, 1993

Abd. Aziz al-Khauli, bin Muhammad, al-Adab al-Nabawi Beirut: Dar al-Fikr, t.th.

Agus Sunyoto, Sejarah Perjungan Sunan Ampel, Surabaya: LPLI Sunan Ampel, t.th.

Abdullah, Hamid. Manusia Bugis Makassar Cet.1; Jakarta : Inti Idayu Press, 1985

Abdullah Warras, Muhammad. al-Nabā al-Ađ̣̂m Nađ̣aratun Jadīdatun fī al-Qur'ān, Cet.III; Kuwait: Dār al-Kalām, 1974

Abdullah Taufik, Sejarah Lokal di Indonesia, Yokyakarta: Gadjamada University Press, 1996

--------, (ed) Agama dan Perubahan sosial, Jakarta: PT. Raja Grafindo Persada, 1996

---------, Islam dan Masyarakat Pantulan Sejarah Indonesia Jakarta : LP3ES, 1987.

Abu Hamid, Passompe, Pengembaraan Orang Bugis, Makassar: Pustaka Refleksi, 2005 
---------, Syekh Yusuf, Seorang Ulama, Sufi dan Pejuang, Jakarta: Yayasan Obor Indonesia, 1994

-, Selayang Pandang Uraian Tentang Islam dan Kebudayaan Orang Bugis Makassar dalam Andi Rasdiyanah Amir, ed., Bugis Makassar dalam Peta Islamisasi, Ujungpandang: IAIN Alauddin 1982

Abu al Husayn Ahmad bin al Faris bin Zakariya, Mu'jam Maqāyis al Lugah Jus II; Mesir: Mustafa al Babi al Halabi wa Auladuh, 1398 H/1969 M

Abu al-Fada' al-Hafiž Ibnsiir al-Dimasyqi, Tafsir al-Qur'ān al-AŽim juz II Beirut: Dar al-Fikr, 1997.

Abu Bakar Ibn Muhammad al Husain, Imam Taqiyuddin. Kifayah al Akhyar juz II, Beirut : Dar al Fikr, tth.

Abu al-Fath al-Bayanuni, Muhammad. al-Madkhal Ilā Ilm al-Da'wah, Beirut : al- Risalah, 1993

Abdul Malik bin Hisyam al Muafiri, Abu Muhammad (Ibnu Hisyam). terj. Fadhli Bahri, Sirah Nabawiyah Ibnu Hisyam, Jakarta: Darul Falah, 2009

Agama RI, Departemen. Al-Qur'a>n dan Terjemahnya, Bandung: Diponegoro, 2007.

Abidin Ahmad, H. Zainal, Piagam Nabi Muhammad saw. onstitusi Negara Tertulis yang Pertama di Dunia, Jakarta: Bulan Bintang, 1973.

Djamil, Fathurrahman. Metode Ijtihād Majlis Tarjih Muhammadiyah (Jakarta: Logos Publishing Hous, 1995

Fazl al Rahman, Membuka Pintu Ijtihad, Bandung: Pustaka, 1984.

Farid Wajdi, Muhammad. Dairah al-Ma'arif al-Qur'ān al-Isyrin Juz VII Beirut: Dar alMa'rifah, 1971.

Fauziah, Mira Urgensi Media dalam Dakwah dalam M. Jaffar Puteh, et.al., Dakwah Tektual dan Kontekstual, Yokyakarta : AK, Group, 2006.

Fuad Abdul Baqi, Muhammad. al Mu'jam al Mufahraz li alfaz al-Qur'ān al Karim Beirut: Dar al Fikr, 1407 H/1987 M

Goenawan Monoharto dkk, Seni Tradisional Sulawesi Selatan, Makassar: Lamacca Press, 2005

Gonggong, Anhar. Abdul Qahar Muzakkar dari Patriot Hingga Pemberontak (Jakarta: Gramedia, 1992.

G. E. Von Gemerbaun (ed) Islam Kesatuan dalam Keragaman. Terjemahan Efendi Yahya,

Glasse, Cyril. “Ahl al-Kitab”, dalam The Concise Enciclopaedia of Islam , San Francisco: Harper, 1991. 
Halilintar Latif dalam M. Thoyibi dkk, Sinergi agama dan Budaya Lokal Surakarta: Muhammadiyah University Press, 2003

Hajar al Asqalany, Ibn. Fath al Bary bi Syarh shahih al Bokhary tk: Maktabah al Salafiyah, t.th.

Hamka, Prinsip-Prinsip Kebijaksanaan Dakwah Jakarta: Pustaka Panjimas, 1990

Ilahi dkk., Wahyu. Pengantar Sejarah Dakwah, Jakarta: Kencana Prenada Media Group, 2007.

http://islamlib.com/id/artikel/kapan-muhammad-saw-lahir

J. Suyuthi Pulungan, Fikh Siyasah Ajaran Sejarah dan Pemikiran, Jakarta: Raja Grafindo Persada, 1995.

K. Hitti, Philp. History Of The Arabs, Terjemah oleh R. Cecep Lukman Yasin dan Dedi Selamet Riyadi, Cet. II; Jakarta: Serambi, 2006.

Mufrodi, Ali. Isla>m Di Kawasan Kebudayaan Arab Cet. I; Jakarta: Logos Wacana Ilmu, 1997.

Muhammad Syafii Antonio, Teladan Sukses dalam Hidup Berbisnis, Cet. V; Jakarta:PLM, 2007.

Qurais Shihab, M. Tafsir al-Misbah, Vol. VII; Jakarta: Mizan, 2005.

Yatim, Badri. Sejarah Peradaban Islam, Jakarta: PT. Raja Grafindo, 2008. 